\title{
Ewa Kozik
}

Szkoła Doktorska

Uniwersytet Śląski w Katowicach

(D) https://orcid.org/0000-0003-1129-0536

\section{Wśród zapisków na marginesie: dziedzictwo „niepokornej” dyscypliny*}

\begin{abstract}
Among Notes on the Margin: the Legacy of an "Unruly" Discipline
Abstract: The aim of this article is to re-examine the methodology of ethnographic research vis a vis the influence of methodology on the shaping of ethnology and cultural anthropology as a scientific discipline. Field research, which presupposes the scholar's active participation and involvement in the life of the group under investigation, as well as the accompanying challenges to such an approach, are here treated as elements that shape the heritage of ethnology, reinforcing its power and securing its place among other disciplines. The author has undertaken the anthropological analysis of excerpts from field notebooks and subjective records by scholars involved in the creation of the Polski Atlas Etnograficzny [Polish Ethnographic Atlas].
\end{abstract}

Keywords: ethnology, heritage, field research, methodology, Polski Atlas Etnograficzny [Polish Ethnographic Atlas]

Słowa kluczowe: etnologia, dziedzictwo kulturowe, badania terenowe, metodologia, Polski Atlas Etnograficzny

\section{Etnografia, etnologia, antropologia kulturowa}

Etnologia to dyscyplina naukowa, której przedstawiciele zajmują się przede wszystkim kulturą. Już pierwsze zdanie tego przyczynku o dziedzictwie naukowym etnologii i antropologii kulturowej przysparza pewne problemy. Kultura to niezwykle szerokie pojęcie będące przedmiotem zainteresowania wielu naukowców, którzy w celu zawężenia obszaru swoich badań skupiają się na wybranych aspektach z szerokiego spektrum subdyscyplin (takich jak przykładowo antropo-

\footnotetext{
* Źródło finansowania badań przedstawionych w artykule: badania własne.
} 
logia miasta, antropologia medycyny, antropologia pogranicza) funkcjonujących w ramach antropologii. Claude Lévi-Strauss pisał, że etnolog próbuje dokonać tego samego opisu, obserwacji, klasyfikacji i interpretacji w dziedzinie kultury, co zoolog w odniesieniu do danego ekosystemu ${ }^{1}$. Etnologia daje badaczom szerokie pole działania, eksplorują oni coraz to nowsze obszary i posługują się narzędziami, które umożliwiają rzetelny opis zastanej rzeczywistości. Również tradycyjne etnologiczne „wyjście w teren”2 nieustannie zmienia swoje znaczenie. Terenem badawczym w etnologii była dawniej chłopska wieś, w dobie postmodernizmu stał się nim sam antropolog, dziś natomiast widzimy wzrost popularności badań internetowych. Zmiany, jakie dokonują się wewnątrz samej dyscypliny, potwierdzają słowa Kristen Hastrup, która w przedmowie do swojej książki Droga ku antropologii stwierdza, że tożsamość naukowa jest tak samo płynna jak tożsamość kulturowa. Hastrup podkreśla również, że każda dyscyplina akademicka jest na swój sposób totalitarna, staje się światopoglądem, poprzez który patrzymy na rzeczywistość ${ }^{3}$. Etnologia sięga do interdyscyplinarności, spójnie łącząc różne koncepcje człowieka, społeczeństwa i kultury, by ciągle na nowo stawać się „sztuką interpretacji przejawów ludzkiej świadomości”4.

Celem w niniejszym artykule jest antropologiczna refleksja nad dziedzictwem etnologii i antropologii kulturowej przez analizę poszczególnych notatek i uwag poczynionych podczas pracy $\mathrm{w}$ terenie. Badania terenowe to swoiste dziedzictwo etnologii i antropologii kulturowej, dlatego są punktem odniesienia tych rozważań jako jej differentia specifica. Analizie poddane zostaną fragmenty dwóch opublikowanych notatników terenowych - Dziennika w ścistym znaczeniu tego wyrazu Bronisława Malinowskiego oraz Wszystko jest cudowne autorstwa Sigrid Rausing. Jednakże głównym przedmiotem refleksji są tytułowe „zapiski na marginesie”, czyli w tym wypadku spontaniczne notatki badaczy terenowych pracujących nad zbieraniem materiałów tworzących dziś Archiwum Polskiego Atlasu Etnograficznego (PAE). Analiza kwestionariuszy PAE ma na celu wskazanie tych elementów, które można potraktować jako subiektywny wkład badaczy w dane zawarte $\mathrm{w}$ kwestionariuszach oraz świadectwo ich uczuć, emocji i trudów przeżywanych podczas pobytu w terenie. Komentarze, wykrzykniki, zdania zapisane w cudzysłowie lub nawiasie itp. są śladem niezachowanych lub nieistniejących notatników terenowych, które na równi z kwestionariuszami stanowią dziedzictwo etnologii i są świadectwem kształtowania się dyscypliny oraz jej metody, określającej odrębności etnologii i antropologii kulturowej w stosunku do innych nauk.

1 G. Charbonnier: Rozmowy z Claude Lévi-Straussem. Przeł. J. Trznadel. Warszawa 1968, s. 140; za: W.J. Burszta: Antropologia kultury. Poznań 1998, s. 39.

${ }_{2}$ Zob. szerzej np. K. KANIOwsKa: Metoda etnograficznych badań terenowych i poznanie w antropologii. W: Teren w antropologii. Praktyka badawcza we wspótczesnej antropologii kulturowej. Red. T. Buliński, M. Kairski. Poznań 2011, s. 287-288.

${ }^{3}$ K. Hastrup: Droga ku antropologii. Przeł. E. Кцекот. Kraków 2008, s. 11.

${ }^{4}$ C. Rовотүскі: Etnografia wobec kultury współczesnej. Kraków 1992, s. 23-27. 


\section{Dziedzictwo etnologii w obliczu kryzysu}

Etnologia i antropologia kulturowa rozwijają się coraz prężniej, w ich ramach tworzone są spójne teorie, pozwalające formułować konkretne odpowiedzi na pytania o inność, rasizm, ksenofobię, a także wielokulturowość i globalizację. Etnologia powstała za sprawą zdziwienia Innym, jest bezpośrednią potomkinią imperialnej i kolonialnej tradycji. W epoce stalinowskiej nazywano ją nauką burżuazyjną, ponieważ u zarania dyscypliny etnolodzy pisali prace głównie o „ludach prymitywnych” oraz o ludności wiejskiej, czemu towarzyszyło odgórne założenie o niższości tych grup społecznych względem wykształconych elit. Choć nie kryliśmy zachwytu nad innością, nie przestawaliśmy się jej obawiać, a ówczesne opisy możemy rozpatrywać jako próbę oswojenia tego, co nieznane. Obecnie etnolodzy rozpisują się na temat funkcjonalnych modeli wielokulturowości, równości oraz zagrożeń ze strony totalitaryzmu i fundamentalizmu. Pracując nieustannie z człowiekiem, badając jego kulturę i styl życia, etnolodzy nieraz szybciej i celniej diagnozują zagrożenia pojawiające się na scenie życia społecznego, w skali lokalnej czy nawet międzynarodowej.

Być może dlatego etnologia, „niepokorna” dyscyplina, której przedstawiciele poruszają trudne tematy, często analizują niedoskonałości społeczno-kulturowego systemu, przeżywa kryzys za każdym razem, gdy w systemie tym zachodzą zmiany. Pierwszy taki kryzys na polskim gruncie antropologii przypadł w epoce stalinowskiej, następny - kiedy w PRL starano się umniejszyć znaczenie kulturoznawstwa, a etnologię wykorzystywano jako sposób na budowanie polskiej tożsamości za pomocą odwoływania się do kultury ludowej ${ }^{5}$. Z kolejnym kryzysem mamy do czynienia obecnie. W 2018 roku Ministerstwo Nauki i Szkolnictwa Wyższego usunęło etnologię z listy dyscyplin naukowych, klasyfikując ją jako jedną z „nauk o kulturze i religii”. Tym samym, etnologia, której przedstawiciele zajmują się interpretacją kultury, została zrównana $\mathrm{z}$ wszelakimi rodzajami kulturoznawstwa oraz religioznawstwem, dyscyplinami różniącymi się od niej przede wszystkim przedmiotem i metodologią prowadzonych badań. Utraciła samodzielność, a zwolennicy tego stanu rzeczy argumentują to jej mniejszą użytecznością i stosowalnością społeczną w stosunku do nauk technicznych lub medycznych ${ }^{6}$. Etnologia, obecna na polskich uniwersytetach od 1919 roku, doznaje poważnej szkody w wyniku zawirowań politycznych, a argumenty o jej rzekomej nieużyteczności to jedynie pewna zasłona dymna.

Warto jednak ponownie zwrócić uwagę na historię antropologii, szczególnie pod kątem wpływu badań terenowych, sztandarowej metody badawczej etno-

${ }^{5}$ Wnioski autorki z badań terenowych prowadzonych podczas realizacji projektu „Etnografia pamięci PRL-u. Kultura codzienności Polski powojennej 1956-1989” (konkurs: OPUS 11, panel: HS3, kierownik projektu: prof. dr hab. Wojciech Burszta, Instytut Slawistyki Polskiej Akademii Nauk), na terenie Katowic i Wrocławia w 2017 roku.

${ }^{6}$ W. Dohnal: Smutny jubileusz. „Lud” 2018, t. 102, s. 13-14. 
logów, na kształtowanie się paradygmatu naukowego. Jurgen Habermas i Max Weber podkreślali, że każda dyscyplina naukowa wymaga od swoich adeptów pewnego zawierzenia jej paradygmatom. Należy zatem bliżej przyjrzeć się temu, co stanowi dziedzictwo tradycyjnej etnologii i co nadal jest $\mathrm{z}$ nią kojarzone. W artykule omówię zatem specyfikę badań terenowych i subtelności dotyczące przebywania $\mathrm{w}$ terenie, których nie uwzględnia się często podczas pisania prac naukowych, prezentujących wyniki odbytych rozmów i poczynionych obserwacji. Chciałabym, aby ponowne spojrzenie na źródła etnologii i antropologii ukazały wagę oraz specyfikę tej dyscypliny.

Dziedzictwo traktuję jako nieustannie kształtującą się, płynną konstrukcję wybranych elementów przeszłości, które stają się szczególnie ważne dla danej grupy i niejako stanowią o jej tożsamości. Podejście to jest kompatybilne z twierdzeniem Zbigniewa Kobylińskiego, który w niemal identyczny sposób definiuje dziedzictwo kulturowe ${ }^{7}$. Skupię się zatem na dziedzictwie dyscypliny akademickiej, etnologii i antropologii kulturowej, które opiera się na doświadczeniu badań terenowych. To one, decydujące o empirycznym charakterze etnologii, stanowią jej siłę i są wyrazem jej odrębności wobec innych nauk.

Czym są badania terenowe? Ta reprezentacyjna dla etnologii i antropologii kulturowej, a zarazem jedna z najważniejszych metod badań jakościowych, której istotne założenia wypracował Bronisław Malinowski, stosowana jest również $\mathrm{w}$ innych dyscyplinach naukowych. $\mathrm{Z}$ metodologicznego dorobku etnologii korzystają dziś między innymi socjolodzy, pedagodzy, politolodzy, ekonomiści ${ }^{8}$. Badania terenowe przyczyniły się również do ukształtowania i rozwoju badań prowadzonych $\mathrm{w}$ przestrzeni wirtualnej, tak istotnej w zrozumieniu całokształtu kultury „cyfrowych tubylców”. W tym ujęciu badania terenowe są dziedzictwem etnologii, polegającym na spotkaniu się twarzą $\mathrm{w}$ twarz $\mathrm{z}$ przedmiotem badań - człowiekiem i kulturą. Studenci pierwszego roku etnologii i antropologii kulturowej często słyszą, że jako etnolodzy będą zajmować się najdelikatniejszą tkanką świata, czyli człowiekiem i jego kruchą pamięcią, o której skarby badacz doprasza się podczas wywiadów pogłębionych. Będąc w terenie, stosując metodę obserwacji uczestniczącej, antropolodzy umieszczają samych siebie w badanym kontekście. Użyte tutaj metafory mają na celu ukazanie delikatności tematu, którym zajmę się w dalszej części pracy. Postaram się opisać sytuację badacza, osoby, która ze względu na potrzeby badawcze porzuca siebie i poddaje się warunkom panującym w terenie.

${ }^{7}$ Z. KoвYlińsкi: Czym jest, komu jest potrzebne i do kogo należy dziedzictwo kulturowe? „Mazowsze. Studia Regionalne” 2011, nr 7, s. 22.

${ }^{8}$ Zob. szerzej, np.: M. Kostera: Antropologia organizacji. Metodologia badań terenowych. Warszawa 2003; M.V. Angrosino: Obserwacja w nowym kontekście. Etnografia, pedagogika, i rozwój problematyki społecznej. W: Metody badań jakościowych. T. 2. Red. N.K. Denzin, Y.S. Lincoln. Warszawa 2009. 


\section{Zwierzenia terenowe}

Znajomość terenu, w którym realizują się badania etnograficzne, daje nam kontekst, dzięki któremu łatwiej jest zrozumieć społeczno-kulturową specyfikę opisywanych fenomenów. Antropolodzy w swoich pracach informują kiedy, gdzie i jak długo prowadzili swoje badania, streszczają relacje $\mathrm{z}$ obserwacji uczestniczących, a swoje wnioski popierają fragmentami przeprowadzonych wywiadów, niekiedy informują też o sprawach intymnych, dotykając wrażliwych kwestii ${ }^{9}$. $\mathrm{O}$ tym, jak naprawdę wygląda praca $\mathrm{w}$ terenie, nauka języka wybranej grupy badanej, poszukiwanie informatorów oraz konieczność zdania się na siebie, informują zazwyczaj niepublikowane, mające prywatny charakter notatki terenowe.

Początkujący adepci etnologii są zachęcani do prowadzenia dzienników, spisywania własnych odczuć, wrażeń i spostrzeżeń niekoniecznie mających związek z przedmiotem badań, aby po powrocie $\mathrm{z}$ terenu mieć przy sobie jego namiastkę, co pozwala wiarygodnie opisać specyfikę i warunki, w jakich przeprowadzane były badania. Najbardziej znanym notatnikiem tego rodzaju jest Dziennik w ścislym znaczeniu tego wyrazu Malinowskiego, tworzony podczas dziesięciu lat badań terenowych. Jak pisze Grażyna Kubica, te intymne zapiski twórcy funkcjonalizmu są odbiciem procesu badań, dzięki którym radził on sobie w terenie. "Jest to dokument szczery do granicy wytrzymałości człowieka", pisany przez Malinowskiego z myślą o ocaleniu Malinowskiego, badacza oddalonego od domu i przyjaciół, osamotnionego wśród ludzi, którzy z pewnością nie pragną zrozumieć go tak samo, jak on ich ${ }^{10}$. Dziennik Malinowskiego jest istotny dla dziedzictwa etnologii i antropologii kulturowej, dlatego, że obnaża sytuację badacza prowadzącego badania $\mathrm{w}$ terenie. Umyślnie użyte słowo „obnaża” ma uzmysłowić niezwykle trudną sytuację człowieka, nieraz osamotnionego, wycieńczonego fizycznie i psychicznie, który zdecydował się na opuszczenie znanego sobie świata w imię nauki.

Poszedłeś naprzód, ale nie doszedłeś granicy. Cóż więc pozostaje? Znów w drogę ruszyć. Czy całe życie ma być takim przesuwaniem swojego ja po linii wewnętrznych możliwości? Na dnie mego obecnego stanu odczuwam jakby lekki cień buntu przeciw obecnej pracy, jakiś ukryty sceptycyzm, poczucie, że tam istnieje coś oderwanego, coś nietkniętego tymi morałami - uśmiech pobłażliwy Buddy .

Zapiski Malinowskiego niejednokrotnie trącą zwątpieniem, zniechęceniem i niemal skrajnym pesymizmem, co stanowi o sile ich oddziaływania i wiarygodności. Uczucia Malinowskiego, jednego z najbardziej znanych teoretyków kultury,

\footnotetext{
${ }^{9}$ Zob. szerzej np. M. Hammersley, P. Atkinson: Metody badań terenowych. Przeł. S. DymCZYK. Poznań 2000.

${ }^{10}$ G. Kubica: Wstęp. W: B. Malinowski: Dziennik w ścisłym znaczeniu tego wyrazu. Kraków 2001, s. 19.

${ }^{11}$ B. Malinowski: Dziennik w ścistym znaczeniu..., s. 42.
} 
są uczuciami prawie każdego badacza znajdującego się w terenie. Są to często smutne zwierzenia osoby, która chwilowo zrezygnowała z konformizmu, by zaspokoić głód badawczej ciekawości, a która została zawiedziona, która być może nie odnajduje tego, co spodziewała się znaleźć. Teren ma to do siebie, że zawsze jawi się etnologom niezwykle obiecująco i nieraz ich zawodzi, grupa osób badanych często okazuje się źle dobrana lub nieufna. Rausing, spisując swoje przemyślenia w dzienniku, podkreśla, że teren badań jest również okazją do poznania samego siebie, nie tylko własnych fizycznych granic, ale również kondycji psychicznej i zdolności radzenia sobie ze stresem.

Żyjąca w Wielkiej Brytanii, a wychowana w Szwecji Sigrid Rausing w latach 1993-1994 prowadziła badania w Estonii, w byłej radzieckiej strefie przygranicznej na półwyspie Noarootsi. Chcąc opisać sytuację estońskich Szwedów oraz zrelacjonować niezwykle trudną zmianę systemową z sowieckiego reżimu na postsowiecką biedę spowodowaną zmianą ustroju na kapitalistyczny, uczyła się języka i wyjechała na rok, by zamieszkać w kołchozie im. Lenina. Wyniki badań opublikowała w rozprawie doktorskiej, natomiast swoje własne doświadczenie tego okresu zawarła w wspomnianej książce Wszystko jest cudowne, opartej na dzienniku prowadzonym podczas badań terenowych. Celem Rausing było ukazanie emocjonalnej strony pracy etnologa oraz przekazanie spostrzeżeń, których ze względów metodologicznych i etycznych nie mogła opisać w rozprawie doktorskiej. Obok obserwowanych wydarzeń umieszcza samą siebie, uwzględniając swoje uczucia, ogromną niepewność wobec wybranego tematu badawczego, trudności radzenia sobie z brakiem dóbr, do których przywykła, z zimnem oraz nieufnością innych, a także zwykłe zmęczenie, wynikające z faktu, że etnolog $\mathrm{w}$ terenie musi być aktywny niemal całą dobę. Jego praca zaczyna się od momentu przebudzenia, a kończy, gdy zamyka oczy do snu. Rausing opisuje również konieczność udawania zadowolenia, wymuszoną uprzejmość wobec niektórych osób z grupy badanej i samotność spowodowaną długotrwałym oddaleniem od domu, bliskich i przyjaciół. Jak zapewne wiele innych, nieznanych dzienników z badań terenowych, książka Rausing jest wyznaniem uczuć, spostrzeżeń i uwag, zarówno negatywnych, jak i pozytywnych, których badaczka nie mogła przedstawić $\mathrm{w}$ swojej pracy naukowej ${ }^{12}$.

Timo popadł w milczenie, wpatrywał się w okno, zagubiony i pogrążony w depresji, bo przyszło mu uczyć przez rok w tej prymitywnej wsi. Ostrożnie przystąpiłam do obserwacji uczestniczącej, podczas gdy on chciał rozmawiać jedynie o współczesnej europejskiej scenie muzycznej - oboje okazaliśmy się dla siebie wielkim rozczarowaniem ${ }^{13}$.

Można powiedzieć, że takie zwierzenia w notatnikach prowadzonych podczas badań terenowych są głosem oddanym subiektywności człowieka, zapisuje się

12 S. Rausing: Wszystko jest cudowne. Przeł. K. OвŁUCKi. Warszawa 2015.

${ }^{13}$ Ibidem, s. 28. 
je w celu ochrony obiektywności i psychicznego odciążenia badacza. Doskonale zdajemy sobie sprawę, że uzyskanie pełnej obiektywności nie jest możliwe, tak samo jak nieosiągalna jest całkowita alienacja osobowościowa badacza podczas prowadzenia wywiadu pogłębionego. Podczas takiej rozmowy zawsze obie strony kształtują otrzymane wyniki, a osoba przeprowadzająca dany wywiad może jedynie starać się ograniczyć swój wpływ na respondenta. Powrócę jednak do czasów, kiedy wierzono w możliwość osiągnięcia obiektywności naukowej, a osoba etnologa podczas prowadzenia badań, jego uczucia, nastawienie, kondycja nie były brane pod uwagę $\mathrm{w}$ tak znacznej mierze jak obecnie. W dalszej części tekstu przybliżę zatem sposób gromadzenia danych źródłowych w ramach Polskiego Atlasu Etnograficznego, który jako zespół rzetelnych informacji stanowi podstawę myślenia i budowania teorii kultury ludowej.

\section{Polski Atlas Etnograficzny}

Według Wojciecha Burszty zainteresowanie kulturą ludową i życiem chłopów wynikało z bliskiej inności tej grupy społecznej, która niejako zastępowała inność ludów pierwotnych, „prymitywnych”, opisywanych przez funkcjonalistów ${ }^{14}$. W kulturze ludowej doszukiwano się inności, jak również tożsamości, korzeni narodowych oraz folkloru, postrzeganego jako to, co pierwotnie, nieskalane negatywnie ujmowaną nowoczesnością i szczere w swojej prostocie. Takie przynajmniej były oczekiwania wobec terenu badawczego, jakim była polska wieś, w której od końca XIX wieku prężnie dążono do udoskonaleń technicznych i zmian społecznych.

Polski Atlas Etnograficzny nieformalnie powstał w 1945 roku. Początkowo traktowano go jako istotne przedsięwzięcie naukowe, w którym od samego początku miało uczestniczyć całe ówczesne środowisko etnologiczne. Nowa rzeczywistość społeczno-kulturowa i podejmowanie odmiennych tematów badawczych zrewidowały jednak te zamierzenia. $\mathrm{Z}$ czasem działalność atlasowa ukonstytuowała się głównie w ramach wrocławskiego środowiska naukowego (później - cieszyńskiego ośrodka badań atlasowych) ${ }^{15}$. Kolejni redaktorzy PAE - Józef Gajek, Janusz Bohdanowicz, Zygmunt Kłodnicki - stworzyli grupę badaczy, składającą się początkowo $\mathrm{z}$ niewykwalifikowanych etnografów amatorów (często folklorystów z zamiłowania), później z wykształconych badaczy społecznych. Pierwsze badania atlasowe miały głównie charakter ankietowy ${ }^{16}$, kolejne przeprowadzano

\footnotetext{
${ }^{14}$ W.J. Burszta: Antropologia kultury..., s. 33.

15 A. Pieńczak: Cyfrowe Archiwum Polskiego Atlasu Etnograficznego w 75-lecie działalności atlasowej. „Dziedzictwo Kulturowe Wsi” 2020, t. 4, s. 1 [maszynopis, artykuł w druku].

${ }^{16}$ Przykładem są pierwsze ankiety atlasowe dotyczące zbieractwa roślin dziko rosnących w celach leczniczych i pokarmowych, realizowane w latach 1948-1952 (zob. szerzej A. Pieńczak:
} 
w ramach badań terenowych odbywających się w około trzystu czterdziestu stałych punktach PAE (zależnie od problematyki badawczej), stanowiących zintegrowaną sieć badawczą. Główną metodą były badania prowadzone w terenie, na których podstawie później zostały opracowane mapy z użyciem metody etnogeograficznej ${ }^{17}$. Józef Gajek tak sformułował cele pracy nad atlasem:

Główne zadania PAE polegają na opracowaniu serii kartogramów obrazujących zróżnicowanie przestrzenne Polski, pod względem inwentarza kulturowego oraz wykrycia zespołu tych faktów kulturowych, które są, względnie były w przeszłości charakterystyczne dla polskiej kultury ludowej i stanowiły czynnik wiążący Polskę w jedną całość etniczną ${ }^{18}$.

Celem opracowania atlasu było więc uchwycenie polskiego dziedzictwa kulturowego, jednocześnie zgromadzone dane stały się znaczącym elementem dziedzictwa naukowego etnologii. Opiekę nad realizacją badań przejmowały kolejno: Polskie Towarzystwo Ludoznawcze, Katedra Etnografii Uniwersytetu Marii Curie-Skłodowskiej w Lublinie, Uniwersytet im. Adama Mickiewicza w Poznaniu, Uniwersytet Wrocławski ${ }^{19}$. Praca nad gromadzeniem i porządkowaniem danych tworzących Polski Atlas Etnograficzny obejmowała wiele etapów: od badań ankietowych, poprzez tworzenie map, redagowanie kwestionariuszy, przeprowadzanie badań terenowych aż po porządkowanie danych i obecną ich digitalizację ${ }^{20}$.

Kwestionariusze, według których przeprowadzono badania, dotyczyły kultury zarówno materialnej (hodowla, rolnictwo, budownictwo, transport i komunikacja lądowa), jak i niematerialnej (obrzędy weselne, urodzinowe, pogrzebowe, demonologia) ${ }^{21}$. Początkowo były to zapiski w zeszytach, bez bazy szczegółowych pytań, i dotyczyły budownictwa, dlatego wiele z zeszytów zapełnionych jest głównie szkicami przedstawiającymi domy, dachy, ściany itp. Podobnie było w przypadku rolnictwa, badacze, ze względu na brak sprzętu fotograficznego, szkicowali narzędzia, których używali mieszkańcy wsi. Inaczej wyglądają kwestionariusze $\mathrm{z}$ lat pięćdziesiątych $\mathrm{XX}$ wieku. Każdy $\mathrm{z}$ nich zawierał ponad sto pytań o różnym poziomie szczegółowości, a w niektórych dodatkowo były zamieszczone rady dotyczące tego, jak prowadzić rozmowy z respondentami, na przykład: „Uwaga,

The Collection of Questionnaires Concerning Wild Plants on the Digital Platform of the Polish Ethnographic Atlas. „Slovenský národopis” 2016, vol. 15, issue 2, s. 228-240).

17 Z. KŁodnicki, A. Pieńczak, J. Koźmińska: „Polski atlas etnograficzny”. Historia, osiagnięcia, perspektywy badawcze. Katowice 2017, s. 20-31.

${ }_{18}$ Polski Atlas Etnograficzny. Zeszyt próbny. Red. J. Gajek. Wrocław 1958, s. 9; cyt. za: ibidem, s. 26 .

19 Z. KŁodnicki, A. Pieńczak, J. Koźmińska: „Polski atlas etnograficzny”..., s. 25-24.

${ }^{20}$ Zob. szerzej: A. Pieńczak: Cyfrowe archiwum Polskiego Atlasu Etnograficznego - możliwości wyszukiwawcze i dalsze perspektywy badawcze. „Lud” 2019, t. 103, s. 207-229.

${ }^{21}$ Wykaz kwestionariuszy PAE opracował między innymi Zygmunt Kłodnicki, zob. Z. KŁodnicki: Polski atlas etnograficzny - historia, stan obecny i perspektywy. „Lud” 2001, t. 85, s. 242-243 [aneks 1]. 
żeby terminy gwarowe również podawać w cudzysłowie”22 lub „Zbadać tzn. postawić pytanie na temat podany $\mathrm{w}$ kwestionariuszu, $\mathrm{w}$ formie, jaką dyktują warunki - na przykład osobowość informatora terenowego"23. Tego typu wskazówki świadczą o trosce twórców PAE, by badania były rzetelne i wiarygodne. Badacze byli wcześniej przygotowani do pracy w terenie i pouczani o znaczeniu swojej działalności. Jednakże znajdując się w nieznanej sobie miejscowości, wśród obcych ludzi, mając zgromadzić dane według na przykład czterech obszernych kwestionariuszy, w przypadku każdego z koniecznością uzyskania odpowiedzi od co najmniej pięciu informatorów, stali przed prawdziwie niełatwym zadaniem. Sytuacja przedstawia się jeszcze trudniej, gdy odkryjemy, że często czas na realizację badań był ograniczony i wynosił około tygodnia, a przecież chodziło o pracę nad kruchą i wrażliwą pamięcią przypadkowo spotkanych osób, czemu pośpiech na pewno nie sprzyja.

\section{Pamięć podlega nastrojom}

Ograniczony czas na przeprowadzenie wywiadów, wymóg zgromadzenia informacji pochodzących od co najmniej pięciu informatorów i inne niezależne od badacza czynniki prawdopodobnie niezbyt korzystnie wpływały na wyniki badań. Kierownik projektu, Józef Gajek, do dziś wspominany jest wśród pracowników PAE jako osoba niezwykle rzetelna, punktualna i staranna, czego wymagał również od zatrudnionych badaczy terenowych. Ich praca była więc często prowadzona pod presją ze strony pracodawców, opiekunów naukowych, samych respondentów, czasu oraz własnych prywatnych zobowiązań. Dodatkowym czynnikiem utrudniającym wykonanie zadania były ograniczone możliwości techniczne. Badacze nie mieli możliwości korzystania z dyktafonów i dokonania na ich podstawie późniejszej transkrypcji, która sprawia, że analiza wywiadu pogłębionego staje się dokładniejsza i przede wszystkim nie jest zdana na łaskę i niełaskę pamięci ${ }^{24}$.

W pracy etnologa szczególną rolę odgrywa nie tylko pamięć respondenta, jako źródło informacji, które zdobywa się podczas rozmowy, ale także pamięć samego badacza, jako ich rezerwuar. Już kilkakrotnie nazwałam pamięć kruchą. Tym określeniem akcentuję bowiem jej ulotny, zmienny i często ka-

${ }^{22}$ Archiwum Polskiego Atlasu Etnograficznego w Cieszynie, Wydział Sztuki i Nauk o Edukacji Uniwersytetu Śląskiego [dalej: APAE], kwestionariusz nr VII pt. Zwyczaje, obrzędy i wierzenia urodzinowe (oprac. J. GAJEK), sygn. PAE 14.24.II, s. 5.

${ }^{23}$ Ibidem, s. 21.

${ }^{24}$ Informacje uzyskane od dr hab. Agnieszki Pieńczak, prof. UŚ, obecnej opiekunki zbiorów zdeponowanych w Archiwum Polskiego Atlasu Etnograficznego oraz kierowniczki Pracowni Digitalizacyjnej Polskiego Atlasu Etnograficznego (Wydział Sztuki i Nauk o Edukacji Uniwersytetu Śląskiego w Katowicach). 
pryśny charakter. Pamięć ulega nastrojom, ponieważ przejawiamy skłonność do zapamiętywania tych rzeczy, które chcemy zapamiętać. Tak jak tożsamość i dziedzictwo, pamięć jest konstrukcją tworzoną według niedookreślonych kryteriów, podlegających społecznym i kulturowym zmianom. Jak pisze Maurice Halbwachs, pamięć jednostki poddaje się pamięci zbiorowej, co daje obietnicę względnej obiektywności badaniom etnograficznym ${ }^{25}$. Badacz dociera do wielu jednostek, wyciągając z ich narracji powtarzalne elementy, ubierając je później w ramy uogólnienia. Praca etnologa i tworzone przez niego teorie są zatem grą subiektywności z obiektywnością, grą, która jest fundamentem antropologicznych dociekań, zaś to, co zostanie zapisane i przekazane przyszłym pokoleniom etnologów, staje się dziedzictwem tej dyscypliny.

Do danych tworzących PAE można podejść na dwa sposoby, w ramach nieoficjalnych nurtów badawczych. W jednym $\mathrm{z}$ nich atlas traktuje się jako niekwestionowany zbiór danych o polskiej kulturze ludowej, który można wykorzystywać i eksplorować podczas dalszych analiz antropologicznych. W drugim nurcie natomiast, zachowując pełny szacunek wobec twórców atlasu i badaczy uczestniczących w przedsięwzięciu, podaje się w wątpliwość te dane, które zostały zebrane w pośpiechu lub nie poświęcono im wystarczającej uwagi. Zarzuca się przykładowo, że przygotowane wcześniej kwestionariusze narzucały badaczom sposób prowadzenia rozmów do tego stopnia, że nie mogli oni zainteresować się zjawiskami, które pojawiły się „przy okazji”, niezależnie od pytań zawartych $\mathrm{w}$ kwestionariuszu ${ }^{26}$.

Niezwykle interesujący w tym kontekście jest przykład badań zrealizowanych we wsi Suszec (koło Pszczyny) na Górnym Śląsku przez Mariana Cieślę, folklorystę amatora i pedagoga. W zakresie obrzędów weselnych lub urodzinowych udało mu się zgromadzić bogaty materiał, ale w przypadku demonologii danych jest niewiele (takie zróżnicowanie dotyczyło zresztą pracy wielu badaczy, ze względu na specyfikę tego tematu). Kwestionariusze dotyczące przykładowo demonologii, zwyczajów urodzinowych, weselnych zawierają osobną stronę przeznaczoną na opis informatorów, gdzie badacze odnotowywali wiek, płeć i zawód swoich rozmówców oraz ich „ocenę" (na przykład „bardzo dobry informator”, "dobra informatorka"), informującą o tym, czy badaczowi udało się uzyskać od danej osoby wystarczającą liczbę odpowiedzi ${ }^{27}$. Co ciekawe, Cieśla charakteryzuje swoich respondentów w taki sposób: „Bardzo dobra informatorka. Zna wiele opowieści o demonach"28. Jednak po przejrzeniu kwestionariusza okazuje się, że

${ }^{25}$ M. Halbwachs: Społeczne ramy pamięci. W: Antropologia pamięci. Red. P. Majewski, M. NAPIóRKowsKi. Warszawa 2018, s. 269-273.

26 A. DrożDż: Re/konstrukcje codzienności. Gdańsk 2018, s. 7-35.

27 APAE, kwestionariusz nr X pt. Demony, półdemony $i$ istoty nadprzyrodzone $w$ opowiadaniach $i$ wierzeniach ludowych (oprac. J. GAJEK), sygn. PAE 8.21.VI, s. VII-VIII.

28 APAE, kwestionariusz nr X pt. Demony, półdemony $i$ istoty nadprzyrodzone $w$ opowiadaniach $i$ wierzeniach ludowych (oprac. J. GAJEK), sygn. PAE 20.34.XV, s. VII-VIII. 
żadna z tych opowieści nie została zapisana. Dlaczego? Prawdopodobnie również dlatego, że nie odpowiadała założeniom badawczym kierowników PAE. Nie było to jednak regułą, ponieważ w Archiwum PAE znajduje się wiele kwestionariuszy dotyczących demonologii, które zostały dobrze opracowane.

Anna Drożdż zaznacza, że wszystkie założenia dotyczące kultury tradycyjnej, a więc i to, co niejako miało zostać odkryte podczas badań atlasowych, opisano jeszcze przed samym rozpoczęciem całego przedsięwzięcia. W pewnym sensie były to badania o charakterze bardziej historycznym niż etnograficznym, miały potwierdzić to, co zostało wcześniej ustalone, nie zawsze uwzględniano pojawiające się nowe aspekty kultury wiejskiej. Wytyczne znajdujące się w kwestionariuszach dotyczyły tego, jak badacz ma „poruszać się w terenie” i w jaki sposób prowadzić wywiad, by rozmowa doprowadziła do uzyskania oczekiwanych wyników. Takie podejście nie pozostawiało często miejsca na negocjacje z rozmówcą ani jakiekolwiek inne interakcje ${ }^{29}$.

Etnografowie wyruszający $\mathrm{w}$ teren byli zaopatrzeni w kwestionariusze oraz instrukcje dotyczące sposobu przeprowadzania badań, a także w coś, co możemy nazwać rodzajem wiedzy potocznej, subiektywnej narracji, dzięki której organizowali swoje działania w terenie badawczym. W Archiwum PAE nie znajdziemy żadnych wzmianek o prowadzeniu dzienników z badań terenowych, możemy się zatem tylko domyślać, jakie uczucia towarzyszyły badaczom i z jakimi trudnościami zmagali się oni podczas zdobywania danych atlasowych. Jeśli odrzucić nienaukowe domysły, pozostaje nam sfera ołówka i marginesu, czyli tego, co często nawet nie zostało napisane, a czego istnienia możemy dowodzić, śledząc charakter pisma etnografa oraz język, jakim się posługiwał, wypełniając kwestionariusze, zdradzający jego zaangażowanie w pracę. Pismo oraz nieśmiałe uwagi poczynione na brzegu zeszytów to jedyne ślady „zwierzeń terenowych” tych badaczy, co zostanie pokrótce zaprezentowane w następnej części artykułu.

\section{„Smutno mi, ale nawet zmora w tej wsi nie jest znana"30}

Tytuł tego podrozdziału to jedna $\mathrm{z}$ nielicznych uwag bezpośrednio zdradzająca uczucia osoby spisującej odpowiedzi do kwestionariusza poświęconego demonologii ludowej. Przeprowadzenie badań na jego podstawie nie całkiem się powiodło, czego wyrazem są liczne puste miejsca w notatnikach. W celu ukazania wspomnianej sfery marginesu i ołówka, będącej dla badaczy terenowych rodzajem dziennika, dokonałam analizy zawartości dwudziestu dwóch kwestionariuszy

${ }^{29}$ A. DROŻDż: Re/konstrukcje..., s. 7-23.

${ }^{30}$ APAE, kwestionariusz nr X pt. Demony, półdemony $i$ istoty nadprzyrodzone $w$ opowiadaniach $i$ wierzeniach ludowych (oprac. J. GAJEK), sygn. PAE 8.24.IX, s. 43. 
dotyczących ludowej kultury materialnej, budownictwa, demonologii ludowej oraz obrzędowości narodzinowej, weselnej i pogrzebowej we wsiach: Siemowo, Świbna, Suszec, Krajkowo, Wiry, Dąbrówka Leśna, Pacholęta, Brwice, Stare Biskupice, Kopce, Wróblów, Kiełpiny, Lewiczynek, Zatom, Walewice, Koperno, Żaganiec, Poświętne, Stary Węgliniec i Objazda. Te przykłady wybrałam losowo, by skupić się na sposobie zapisywania danych, bez względu na miejsce, w którym przeprowadzane były badania. W materiale starałam się odnaleźć ślady świadczące o zaangażowaniu i odczuciach badaczy pracujących nad PAE, za które uznaję wspomniane już notatki na marginesach, podkreślenia, zmianę $\mathrm{w}$ staranności pisma, zdania $\mathrm{w}$ nawiasach itp.

Badaczka zbierająca dane we wsi Pacholęta ${ }^{31}$ na temat zwyczajów i obrzędów pogrzebowych przeprowadziła wywiady aż $\mathrm{z}$ dwudziestoma czterema informatorami. Przed zanotowanymi przez nią odpowiedziami odnajdujemy również notatkę, w której w kilku zwięzłych zdaniach tłumaczy się z pewnych nieścisłości w swoim kwestionariuszu. Uznaje go za dobry, podkreśla jednak, że niektóre odpowiedzi mogły być bardziej szczegółowe. Można wnioskować, że badaczka zdawała sobie sprawę z licznych zmiennych wpływających na jakość odpowiedzi respondentów i czuła potrzebę podkreślenia tego faktu już na samym początku kwestionariusza. Generalnie jej zapiski są zwięzłe i rzeczowe, odpowiada pełnymi zdaniami, nawet, jeśli wielu z rozmówców nie miało nic do powiedzenia na dany temat. Jednakże zapis wygląda tak, jak gdyby tych dwudziestu czterech informatorów mówiło jednym głosem. Przy niektórych wypowiedziach znajdują się adnotacje, że badaczka ocenia daną wypowiedź jako szczególnie ważną, jednak nie wyjaśnia, dlaczego tak uważa.

Podobny stopień zaangażowania można zauważyć w przypadku badaczki prowadzącej wywiady według tego samego kwestionariusza we wsi Brwice ${ }^{32}$. Opis informatorów jest bogaty, wskazuje na upodobania respondentów, sposób ich życia, a nawet osobowość, co zdradza personalny stosunek do rozmówców. W podanej charakterystyce wsi również ujawnia się zaangażowanie, badaczka opisuje jej wygląd, co ciekawsze elementy zabudowań oraz specyfikę grupy badanej. Te detale składają się na obraz badacza zanurzonego w teren, co miało zapewne wpływ na jakość przeprowadzanych badań. Badaczka zapisuje dokładne informacje, podpisuje wypowiedzi imieniem i nazwiskiem respondentów, a jej notatki są jasne, czytelne i zwięzłe. Bardziej interesujące, charakterystyczne wypowiedzi podawane są w cudzysłowie. Badaczka zamieściła nawet własnoręcznie wykonany rysunek - babki, którą dawniej piekło się na stypę.

${ }^{31}$ APAE, kwestionariusz nr VIII pt. Zwyczaje, obrzędy i wierzenia pogrzebowe (oprac. J. GAJEK), sygn. PAE 6.16.VIII, s. VII-VIII.

${ }^{32}$ APAE, kwestionariusz nr VIII pt. Zwyczaje, obrzędy i wierzenia pogrzebowe (oprac. J. GAJEK), sygn. PAE 6.17.XII/XVI. 
Ten sam kwestionariusz posłużył badaczowi realizującemu badania we wsi Stare Biskupice ${ }^{33}$, jednak $\mathrm{w}$ tym przypadku mamy do czynienia $\mathrm{z}$ całkiem innym podejściem do terenu badawczego. Już na pierwszych stronach kwestionariusza odnajdujemy surowo brzmiącą uwagę badacza: „Prowadziłem wywiady kontrolowane!"34. Puste strony zostały wykorzystane do odnotowania informacji, które nie odpowiadały wymaganiom kwestionariusza, czyli wytycznym kierowników PAE. Niektóre pozyskane dane, choć są bardzo szczegółowe i skrupulatnie zapisane, nie zostały ostatecznie wzięte pod uwagę podczas analizy zebranych informacji, ponieważ dotyczyły odległego czasu (pół wieku przed badaniami) i bliżej nieokreślonej miejscowości, co oznaczało brak przydatności w tworzeniu map atlasowych według metody etnogeograficznej. Była to stosunkowo konsekwentna selekcja danych. Czerwone podpisy na stronach kwestionariusza świadczą o wątpliwościach kierowników PAE co do jakości niektórych z pozyskanych informacji.

Badacze prowadzący badania kwestionariuszowe dotyczące zwyczajów, obrzędów i praktyk weselnych i urodzinowych przejawiali różne zaangażowanie badawcze oraz stosunek do rozmówców. Etnograf pracujący we wsi Siemowo sporządził rzetelny rejestr wypowiedzi informatorów, których opisał jako „bardzo dobrych” lub „doskonałych”35. Pozyskane odpowiedzi najwyraźniej były wpisywane nie w trakcie wywiadu, ale później, ponieważ są ułożone według pytań, nie widać też śladów po ołówku ani skreśleń. Można przypuszczać, że badacz notował odpowiedzi na brudno, a następnie je porządkował. Jednakże charakter pisma nie zawsze jest schludny, w niektórych momentach nawet nieczytelny, co z kolei kwestionuje właśnie postawioną tezę. Być może badacz zapisywał odpowiedzi naprędce, wyłapując najbardziej potrzebne mu informacje. Czasem adnotacje do danej strony kwestionariusza zostały zamieszczone $\mathrm{w}$ dalszej jego części, na przykład na stronie 42 znajdują się odpowiedzi dotyczące pytania ze strony 37, co znaczy, że badacz później zdobył jakąś informację lub przypomniał ją sobie z opóźnieniem.

\section{Wnioski}

Dane zgromadzone $\mathrm{w}$ Archiwum PAE są w znacznym stopniu odpersonalizowane, widoczne jest $\mathrm{w}$ nich nastawienie na fakty i zdobycie jasnego potwierdzenia lub zaprzeczenia określonych informacji zaczerpniętych $\mathrm{z}$ literatury naukowej analizowanej w celu opracowania kwestionariusza. Prawdopodobnie

${ }_{33}$ APAE, kwestionariusz nr VIII pt. Zwyczaje, obrzędy i wierzenia pogrzebowe (oprac. J. GAJEK), sygn. PAE 7.20.IX.

${ }^{34}$ Ibidem, s. X.

${ }^{35}$ APAE, kwestionariusz nr VII pt. Zwyczaje, obrzędy i wierzenia urodzinowe (oprac. J. GAJEK), sygn. PAE 14.24.II, s. VII-VIII. 
jednak w tamtym okresie nie można było zrobić tego inaczej. Autorzy kwestionariuszy powoływali się bowiem na wcześniejsze doświadczenia etnokartograficzne Kazimierza Moszyńskiego ${ }^{36}$, nastawionego na tworzenie map i wykrywanie tego, co w ogólnie ujętej polskiej kulturze ludowej było dominujące.

Wykrzykniki, pytania, skromne zwierzenia dostrzegalne na kartach arkuszy atlasowych są namiastką subiektywności badacza, zwalczanej przez twórców PAE. Ich intencje oraz cele są absolutnie zrozumiałe i uprawomocnione, a dla zainteresowanych ową ukrytą narracją atlasu pozostaje sfera marginesu i ołówka. Rozpoczynając pracę nad tym artykułem, tak ubogim wobec ogromu informacji, jakie jeszcze skrywają materiały PAE, obawiałam się, że moje wnioski będą z konieczności jedynie domysłami. Archiwum PAE pod tym względem przerosło moje oczekiwania. Ukazało mi ono specyfikę badań terenowych pod innym kątem - nie tylko ich trudy i ograniczenia, ale również potencjał zmuszający badacza do uchwycenia i podkreślenia kontekstu, w którym się znajduje. Zapiski na marginesach, na tyłach stron, okładkach, podkreślenia i wykrzyknienia świadczą o potrzebie rzetelnego opisu zastanej rzeczywistości kulturowej, jeżeli nawet jej charakterystyka nie mieściła się zbytnio w założeniach badawczych poprzedzających wyjście w teren. Etnografowie pracujący dla PAE ulegli tej potrzebie i pomimo wspomnianych ograniczeń starali się przekazać to, czego było im dane doświadczyć podczas realizacji projektu.

Etnologia jako dyscyplina naukowa to doświadczenie, nauka na wskroś empiryczna, a metody w niej stosowane prowadzą do rzetelnego opisu terenu, na którym działają etnolodzy, angażując cały swój profesjonalizm i badawczą intuicję. Być może właśnie te cechy powinny być akcentowane w dobie jej kolejnego kryzysu, kiedy jej znaczenie i użyteczność są uparcie kwestionowane. Polityka, sytuacja ekonomiczna i swego rodzaju „trendy" panujące w świecie naukowym nie powinny odbierać antropologom siły w obronie swojej dyscypliny. Dzięki własnym narzędziom i metodom etnologia pozostanie „sama i dzielna”, nawet jeśli nie będzie widniała w rejestrach jako samodzielna dyscyplina. To „teren” czyni ją wyjątkową na tle innych nauk, wymagając od etnologów odwagi do rezygnacji z poczucia własnego komfortu i zmagania się z osobistymi ograniczeniami.

\section{Bibliografia}

Angrosino M.V.: Obserwacja w nowym kontekście. Etnografia, pedagogika, i rozwój problematyki społecznej. W: Metody badań jakościowych. T. 2. Red. N.K. Denzin, Y.S. Lincoln. Warszawa 2009, s. 129-152.

${ }^{36}$ Współtwórca pierwszego europejskiego atlasu etnograficznego pt. Atlas kultury ludowej $w$ Polsce (zob. K. Moszyński, J. Klimaszewska: Atlas kultury ludowej w Polsce. Z. 1. Kraków 1934; K. Moszyński, J. Klimaszewska, M. Bytnarówna: Atlas kultury ludowej w Polsce. Z. 2. Kraków 1935; K. Moszý́ski, J. Klimaszewska: Atlas kultury ludowej w Polsce. Z. 3. Kraków 1936). 
Burszta W.J.: Antropologia kultury. Poznań 1998.

Charbonnier G.: Rozmowy z Claude Lévi-Straussem. Przeł. J. Trznadel. Warszawa 1968.

Donhal W.J.: Smutny jubileusz. „Lud” 2018, t. 102, s. 13-15.

DrożDż A.: Re/konstrukcje codzienności. Gdańsk 2018.

Halbwachs M.: Społeczne ramy pamięci. W: Antropologia pamięci. Red. P. Majewski, M. NAPIóRKowsKi. Warszawa 2018, s. 269-275.

Hammersley M., Atkinson P.: Metody badań terenowych. Przeł. S. Dymczyк. Poznań 2000.

Hastrup K.: Droga ku antropologii. Przeł. E. KLeKot. Kraków 2008.

Kaniowska K.: Metoda etnograficznych badań terenowych i poznanie $w$ antropologii. W: Teren $w$ antropologii. Praktyka badawcza we wspótczesnej antropologii kulturowej. Red. T. BulIŃski, M. KaIRSKi. Poznań 2011, s. 277-290.

KŁodNicki Z.: Polski atlas etnograficzny - historia, stan obecny i perspektywy. „Lud” 2001, t. 85, s. $239-275$.

KŁodnicki Z., Pieńczak A., Koźmińska J.: „Polski atlas etnograficzny”. Historia, osiagnięcia, perspektywy badawcze. Katowice 2017.

KовYLIŃsкi Z.: Czym jest, komu jest potrzebne i do kogo należy dziedzictwo kulturowe? „Mazowsze. Studia Regionalne" 2011, nr 7, s. 21-47.

Kostera M.: Antropologia organizacji. Metodologia badań terenowych. Warszawa 2003.

Kubica G.: Wstęp. W: B. MalinowsKi: Dziennik w ścislym znaczeniu tego wyrazu. Kraków 2001, s. $7-90$.

MaLinowski B.: Dziennik w ścisłym znaczeniu tego wyrazu. Kraków 2001.

Moszyński K., Klimaszewska J.: Atlas kultury ludowej w Polsce. Z. 1. Kraków 1934.

Moszyński K., Klimaszewska J.: Atlas kultury ludowej w Polsce. Z. 3. Kraków 1936.

Moszyński K., Klimaszewska J., Bytnarówna M.: Atlas kultury ludowej w Polsce. Z. 2. Kraków 1935.

Pieńczak A.: The Collection of Questionnaires Concerning Wild Plants on the Digital Platform of the Polish Ethnographic Atlas. „Slovenský národopis” 2016, vol. 15, issue 2, s. 228-240.

Pieńczak A.: Cyfrowe archiwum Polskiego Atlasu Etnograficznego - możliwości wyszukiwawcze $i$ dalsze perspektywy badawcze. „Lud” 2019, t. 103, s. 207-229.

Pieńczak A.: Cyfrowe Archiwum Polskiego Atlasu Etnograficznego w 75-lecie działalności atlasowej. „Dziedzictwo Kulturowe Wsi” 2020, t. 4 [maszynopis, artykuł w druku].

Polski Atlas Etnograficzny. Zeszyt próbny. Red. J. Gajek. Wrocław 1958.

Rausing S.: Wszystko jest cudowne. Przeł. K. ОвєUскі. Warszawa 2015.

Rовотүскі C.: Etnografia wobec kultury wspótczesnej. Kraków 1992.

\section{Materiały archiwalne}

Kwestionariusze z Archiwum Polskiego Atlasu Etnograficznego w Cieszynie. Wydział Sztuki i Nauk o Edukacji Uniwersytetu Śląskiego w Katowicach:

Kwestionariusz nr VII pt. Zwyczaje, obrzędy i wierzenia urodzinowe (oprac. J. GAJEK), sygn. PAE 14.24.II.

Kwestionariusz nr VIII pt. Zwyczaje, obrzędy i wierzenia pogrzebowe (oprac. J. GAJEK), sygn. PAE 6.16.VIII.

Kwestionariusz nr VIII pt. Zwyczaje, obrzędy $i$ wierzenia pogrzebowe (oprac. J. GAJEK), sygn. PAE 6.17.XII/XVI.

Kwestionariusz nr VIII pt. Zwyczaje, obrzędy $i$ wierzenia pogrzebowe (oprac. J. GAJEK), sygn. PAE 7.20.IX. 
Kwestionariusz nr X pt. Demony, półdemony i istoty nadprzyrodzone w opowiadaniach $i$ wierzeniach ludowych (oprac. J. GAJEK), sygn. PAE 8.21.VI.

Kwestionariusz nr X pt. Demony, półdemony $i$ istoty nadprzyrodzone w opowiadaniach $i$ wierzeniach ludowych (oprac. J. GAJEK), sygn. PAE 8.24.IX.

Kwestionariusz nr X pt. Demony, półdemony $i$ istoty nadprzyrodzone w opowiadaniach $i$ wierzeniach ludowych (oprac. J. GAJEK), sygn. PAE 20.34.XV.

Kwestionariusz nr XVII pt. Zwyczaje, obrzędy i wierzenia urodzinowe (oprac. J. GAJEK), sygn. PAE 14.24.II. 